\title{
THE IMPLEMENTATION OF ECONOMIC, SOCIAL AND Cultural RightS IN CANADA: BETWEEN UTOPIA AND REALITY
}

\author{
Miriam Cohen* \\ Faculty of Law, Université de Montréal [University of Montreal], Canada \\ miriam.cohen@umontreal.ca \\ Martin-Olivier Dagenais ${ }^{* *}$ \\ Harvard Law School, Cambridge, United States \\ mdagenais@llm21.law.harvard.edu
}

Received: 4 March 2020 | Last Revised: 17 February 2021 | Accepted: 24 March 2021

\begin{abstract}
Canada has been at the forefront of the recognition of human rights, including economic, social and cultural rights (ESC rights) in the international scene. As a party to the International Covenant on Economic, Social and Cultural Rights, ${ }^{1}$ Canada has, over the years, implemented in legislation and case-law some ESC rights such as the right to health, education and social welfare. While ESC rights were not explicitly identified in the Charter of Rights and Freedoms, ${ }^{2}$ which forms part of the Canadian Constitution, ESC rights in different forms have received some protection in the Canadian legal order. An analysis of the Canadian record with respect to ESC rights demonstrates the immense gap between a glorified image of Canada as an international human rights proponent (the 'utopia') and the actual implementation of internationally recognized human rights in Canada

Assistant Professor of International Law at Université de Montréal, Canada. Member of the Quebec Bar. Former Legal Counsel before the International Tribunal for the Law of the Sea and Associate Legal Officer at the International Court of Justice. PhD (Leiden University); LLM (Harvard Law School); LLM (Cantab); LLM and LLB (Université de Montréal).

** LLM candidate, Harvard Law School; LLB (Université de Montréal).

1 International Covenant on Economic, Social and Cultural Rights, Dec. 16, 1966, 993 UNTS 3 (entered into force Jan. 3, 1976, accession by Canada May 19, 1976) [ICESCR].

2 Canadian Charter of Rights and Freedoms, Part I of the Constitution Act, (1982), being Schedule B to the Canada Act of 1982 (UK), (1982), c. 11.
\end{abstract}


(the 'reality'). As Canada is bound to face major transformational changes to its economy and social fabric in the years to come, the Courts will have to adapt quickly and efficiently to ensure a smooth transition. This paper overviews the evolution of the case-law on ESC rights in Canada in light of its international obligations, and suggests, the relevant ESC rights jurisprudence signals a disconnect with Canada's international obligation 'requiring progressive implementation to the maximum of available resources by all appropriate means.'

Keywords: Canada, Charter of Rights and Freedoms, Comparative Constitutional Law, ESC Rights, International Human Rights.

"We are not so traditionally accustomed [...] to say that without an employment
insurance law, or without an old pensions law, or laws providing for free
universal education, there is no liberty ... The object of these laws is to free
men and women from known and certain risks which exist in our industrialised
society, and which if not insured against can destroy so much liberty among
so many individuals as to make Bills of Rights to them a hollow mockery."3

\section{INTRODUCTION}

Canada has been at the forefront of the global recognition of human rights, including economic, social and cultural rights (ESC rights). As a party to the International Covenant on Economic, Social and Cultural Rights (ICESCR), ${ }^{4}$ Canada has, over the years, recognised some ESC rights such as the right to health, education and social welfare $t$ hrough legislation and case-law. The highest level of protection for ESC rights in Canada is to recognize them as constitutional rights. While ESC rights were not identified in the Charter of Rights and Freedoms, ${ }^{5}$ which forms part of the Canadian Constitution, ESC rights in different forms have received some protection in the Canadian legal order. However, recent decisions in Canada give grounds for concern about the future and constitutional status of ESC rights in Canada. To abide by its international law obligations, Canada has to provide greater protection for ESC rights.

Francis R. Scott, "Expanding Concepts of Human Rights," in Essays on the Constitution (Toronto: University of Toronto Press, 1977), 357, DOI: https://doi.org/10.3138/9781487583828-027 cited in Martha Jackman, "The Protection of Welfare Rights Under the Charter," Ottawa Law Review 20 (1988): 257.

4 ICESCR.

5 Canadian Charter of Rights and Freedoms (1982). 
This paper proceeds as follows. First, it briefly reviews the international and Canadian frameworks for the protection of ESC rights. It then discusses the interaction between fundamental constitutionally recognized rights and ESC rights, in particular the Canadian Charter of Rights and Freedoms, and recent case-law concerning ESC rights. Through an analysis of the evolution of some key cases relating to ESC rights, including recent examples, it concludes that an increased recognition of ESC rights in laws and policies is necessary to face contemporary socio-economic challenges.

\section{THE INTERNATIONAL AND CANADIAN CONSTITUTIONAL FRAMEWORKS CONCERNING ECONOMIC, SOCIAL AND CULTURAL RIGHTS: CONNECTING THE DOTS}

In order to fully understand the legal framework of ESC rights in Canada it is necessary to briefly examine the constitutional and international contexts in which they are embedded. Indeed, the path to full recognition of these rights in Canada is more challenging than that of many other human rights protected by the Canadian Constitution. In some respects, the struggle for such recognition is as much a tale of major legal and social advances as it is one of conflict between marginalized people in Canadian society and a government that often capitalizes on the silence of the Canadian Constitution, and in particular the Canadian Charter of Rights and Freedoms, ${ }^{6}$ to formally recognize constitutional status to ESC rights.

First, a brief overview of Canada's international obligations explains the two current opposing paradigms with respect to ESC rights among Canadian jurists. Then, in order to shed light on how these obligations are incorporated into Canada's social and legal realities, it is important to better situate economic and social rights at the constitutional level and thereby establish the central role of the Charter throughout this whole issue.

Canadian Charter of Rights and Freedoms (1982). 


\subsection{Canada's International Human Rights Obligations}

Canada's international obligations with respect to ESC rights are found in the ICESCR, which Canada ratified in $1976 .{ }^{7}$ Canada has not however ratified the Optional Protocol to the ICESCR concerning a complaints procedure for victims of violations of ESC rights. ${ }^{8}$

It is important to mention at this juncture, in order to clarify the context, that Article 11 (1) of the ICESCR recognizes the right to a certain standard of living: "The State Parties to the present Covenant recognize the right of everyone to an adequate standard of living for himself and his family, including adequate food, clothing and housing, and to the continuous improvement of living conditions. The State Parties will take appropriate steps to ensure the realization of this right ..."9

Nevertheless, a number of Canadian constitutional law commentators were in disagreement on the question of the recognition of ESC rights in the Canadian legal order when the Charter was adopted. The debate concerned primarily the question of the existence of positive or negative obligations in relation to these rights.

A review of one of the most critical obstacles to ESC rights in Canadian law demonstrates that more must be done to move from the utopian rhetoric of recognition, to full implementation. Attaining the full and unconditional recognition of ESC rights is not a uniquely Canadian challenge but rather a global one. Although it is generally accepted that, in theory human rights are indivisible and of equal importance, the practical extent of this notion is questionable. ${ }^{10}$ In reality, the state's treaty-based human rights obligations will often vary depending on the right at stake. It is the categorization of the latter as a civil and political right on the one hand, or an economic, social and cultural right, on the other, that will be the decisive factor." This difference

Martha Jackman and Bruce Porter, eds., Introduction, Advancing Social Rights in Canada (Toronto: Irwin Law, 2014 ), 1-32. ICESCR, sec. 11 (1).

John H. Currie et al., International Law: Doctrine, Practice and Theory, $2^{\text {nd }}$ ed. (Toronto: Irwin Law, 2014 ), 609.

Currie et al., International Law: Doctrine, Practice and Theory. 
in the practical development of these two types of rights can be explained in particular by the language used in the two treaties concerned, namely the International Covenant on Civil and Political Rights (ICCPR) ${ }^{12}$ and the ICESCR. The terms used in the ICCPR are far more demanding, requiring a certain immediacy and precision that is not reflected in the ICESCR. ${ }^{3}$

By contrast, the ICESCR is characterized by its very gradual approach to the implementation of most of the obligations it contains, thus giving states a fairly wide margin of maneuver prima facie. ${ }^{14}$ Not to mention that these rights, in contrast to civil and political rights, are subjected to a whole other dimension in relation to the availability of resources, making it all the more difficult to obtain the interest of governments to address them. ${ }^{15}$

It comes as no surprise that several governments have been able to take advantage of this textual vagueness to defend their low implementation record in this regard. It is precisely this argument that Canada has used when it questioned the proposal for an optional protocol to the Covenant that would create an individual petition mechanism for the ICESCR.

Thus, challenging the viability of ensuring the implementation of all rights by an adjudicative-type process, Canada addressed the very content of the rights enshrined in the treaty: "The creation of an optional protocol to the International Covenant on Economic, Social and Cultural Rights may be premature where the core requirements of those rights have yet to be defined with precision." ${ }^{16}$ Canada went on to insist that civil and political rights could be distinguished from ESC rights, the former being much more developed and established. ${ }^{17}$ Finally, in reviewing the progressive obligation imposed by Article 2 of the ICESCR, Canada emphasized the imprecise nature of such a duty:

2 International Covenant on Civil and Political Rights, Dec. 19 ,1966, 999 UNTS 171 (entered into force March 1976, accession by Canada May 19, 1976).

13 Currie et al., International Law: Doctrine, Practice and Theory, 614.

14 Philip Alston and Ryan Goodman, International Human Rights (Oxford: Oxford University Press, 2013 ), 285.

15 Alston and Goodman, International Human Rights, 316.

16 UN Doc. E/CN.4/1998/84/Add. 1, par. 1.

${ }_{17}$ William A. Schabas and Stéphane Beaulac, International Human Rights Law: Legal Commitment, Implementation and the Charter, $3^{\text {rd }}$ ed. (Toronto: Thomson Carswell, 2007), 181. 
"Moreover, the difficulty of determining the core requirements of the rights in the Covenant is greatly exacerbated by the obligation in article 2 to achieve progressively the full realization of the rights recognized in the ... Covenant". ${ }^{18}$

\subsection{Constitutional Recognition of Fundamental Rights}

In 1982, the adoption of the Canadian Charter of Rights and Freedoms gave certain rights and freedoms the highest level of protection by granting them constitutional status. With Section 52 of the Constitution Act of 1982 conferring supreme status to the Canadian Constitution and rendering ineffective legal provisions contrary to it, the rights protected by the Canadian Charter of Rights and Freedoms benefit from significant barriers that prevent federal and provincial governments from abusing them at their own discretion. ${ }^{19}$ Indeed, the Charter can only be amended by a complex constitutional amendment procedure that requires the participation and approval of several Canadian parliaments. ${ }^{20}$ The scope of application of the Charter is set out in its Article 32. ${ }^{21}$ Only governments and parliaments are subjected to it and the Canadian Charter does not directly apply to the conduct of private persons. ${ }^{22}$

It is precisely the absence of an explicit reference to ESC rights in the Charter that is at the root of the legal uncertainty surrounding the constitutional nature of these rights in Canada. ${ }^{23}$ As opposed to the Québec Charter of Human Rights and Freedoms, ${ }^{24}$ which provides explicit recognition for some social rights (e.g., free public education), specific social, economic and cultural rights are not mentioned in the Canadian Charter of Rights and Freedoms, but the provisions relating to equality (Article 15) and the

${ }_{18}$ UN Doc. E/CN.4/1998/84/Add. 1, par. 3.

19 Constitution Act, (1982), sec. 35, being Schedule B to the Canada Act 1982 (UK), (1982), C. 11, sec. 52.

20 Henri Brun, Guy Tremblay and Eugénie Brouillet, Droit constitutionnel [Constitutional Law], 6th ed., (Cowansville: Editions Yvon Blais, 2008), 951.

21 Canadian Charter of Rights and Freedoms, (1982), sec. 32.

22 Brun, Tremblay and Brouillet, Droit constitutionnel [Constitutional Law], 977.

23 Martha Jackman and Bruce Porter, "Socio-Economic Rights Under the Canadian Charter," in Social Rights Jurisprudence: Emerging Trends in International and Comparative Law, ed. Malcolm Langford (Cambridge, New York: Cambridge University Press, 2008), 209.

24 Charter of Human Rights and Freedoms, RSO, C C12, Chapter IV. 
right to life, liberty and security of the person (Article 7 ) have provided the basis for cases relating to the recognition of ESC rights, as discussed below.

Be that as it may, the absence of express recognition of ESC rights in the Canadian Charter leads to two possible constitutional interpretations, generally put forward respectively by government actors on the one hand, and by the various organizations campaigning for the recognition of ESC rights on the other. ${ }^{25}$ Insisting on the apparent absence of an express reference to these rights in the constitution allows governments to evade the responsibilities related to them by arguing that said absence results from a political choice by the legislator to remove these issues from the jurisdiction of the Courts and leave them exclusively in the hands of the legislatures. ${ }^{26}$

\section{THE EVOLUTION OF ESC RIGHTS JURISPRUDENCE IN CANADA: AN OVERVIEW}

It is through Section 7, which recognizes to "[e]veryone ... the right to life, liberty and security of the person and the right not to be deprived thereof except in accordance with the principles of fundamental justice", and Section 15, which refers to the right to equality, that the most important part of the debate regarding the recognition of ESC rights in the Canadian Charter has been unfolding. ${ }^{27}$ Section 15 provides that:

15. (1) Every individual is equal before and under the law and has the right to the equal protection and equal benefit of the law without discrimination and, in particular, without discrimination based on race, national or ethnic origin, colour, religion, sex, age or mental or physical disability.

(2) Subsection (1) does not preclude any law, program or activity that has as its object the amelioration of conditions of disadvantaged individuals or groups including those that are disadvantaged because of race, national or ethnic origin, colour, religion, sex, age or mental or physical disability.

Given that there is no explicit recognition of ESC rights in the Charter, in a number of cases, claimants have relied on Section 7 and Section $15 .{ }^{28}$ The

\footnotetext{
Jackman and Porter, "Socio-Economic Rights Under the Canadian Charter," 843.

Jackman and Porter, "Socio-Economic Rights Under the Canadian Charter," 209.

Canadian Charter of Rights and Freedoms, (1982), sec. 7, 15.

8 For a review of relevant jurisprudence, see Jackman and Porter, "Socio-Economic Rights Under the Canadian Charter."
} 
Supreme Court has implied in previous cases that the Charter could protect economic and social rights to some extent ${ }^{29}$ and has recognized that it places both positive and negative duties on different levels of government. The paradigm of positive and negative rights under the Charter jurisprudence, and in particular in relation to ESC rights, has caught the attention of many human rights and constitutional scholars over the years. ${ }^{30}$ As Martha Jackson and Bruce Porter put it:

The problematic and now widely discredited distinction between justiciable civil and political rights and non-justiciable social rights has a number of adverse consequences for Charter interpretation, however. When they are conceived solely as negative rights, broadly framed guarantees, such as rights to life and security of the person, are whittled down to freedom from government interference and stripped of their social rights content. The effect is to disenfranchise disadvantaged groups from the protection of section 7 [...] Moreover, a negative rights framework reduces section 15the very Charter section that was drafted to ensure substantive rather than formal equality for disadvantaged groups-to a guarantee of freedom simply from direct discrimination. ${ }^{31}$

Providing the examples of many countries from all corners of the world, such as Colombia, Brazil, Portugal, South Korea, South Africa and others, Ania Kwadrans argues that the "distinction between positive and negative rights has now largely been rejected by the international community and in academic circles. The justiciability of ESR has also been established through national constitutions that incorporate ESR as legally enforceable and constitutionally binding." ${ }^{32}$ In a

29 Martha Jackman and Bruce Porter, "Social and Economic Rights" in The Oxford Handbook of the Canadian Constitution, eds. Peter Oliver, Patrick Macklem, and Nathalie Des Rosiers (Oxford: Oxford University Press, 2017), 848 .

30 Concerning the debate between positive and negative rights, see generally Ania Kwadrans, "Socioeconomic Rights Adjudication in Canada: Can the Minimum Core Help in Adjudicating the Rights to Life and Security of the Person under the Canadian Charter of Rights and Freedoms?" Journal of Law and Social Policy 25, (2016): 78-108; Margot Young, "Charter Eviction: Litigating Out of House and Home," Journal of Law and Social Policy 24 (2015): 46; Malcolm Langford, "The Justiciability of Social Rights: From Practice to Theory," in Social Right Jurisprudence: Emerging Trends in International and Comparative Law, ed. Malcolm Langford (New York: Cambridge University Press, 2008); Cass R Sunstein, "Social and Economic Rights? Lessons from South Africa," Constitutional Forum 11, no. 4 (2001): 123.

${ }_{31}$ Martha Jackman and Bruce Porter, "Introduction, Advancing Social Rights in Canada," Irwin Law (November 2015 ): 13.

32 Ania Kwadrans, "Socioeconomic Rights Adjudication in Canada: Can the Minimum Core Help in Adjudicating the Rights to Life and Security of the Person under the Canadian Charter of Rights and Freedoms?"Journal of Law and Social Policy 25 (2016): 83. 
similar comparative analysis, Katharine Young draws on constitutional examples to argue that "processes of interpretation, enforcement, and contestation each reveal how economic and social interests can be protected as human and constitutional rights, and how their protection changes public law".33

Nevertheless, decades after the adoption of the Charter, and the broken illusion that ESC rights could make their way into a jurisprudential construction of fundamental rights recognized in the Charter, such as Articles 7 and 15, it is now clear that the "bifurcation of positive and negative rights as a simplistic solution to the separation of powers has thus seriously undermined the inclusive paradigm of social rights for which women, people with disabilities and other stakeholders fought". ${ }^{4}$ Having overviewed the constitutional framework for the recognition of ESC rights through judicial interpretation of fundamental constitutional rights, we now turn to the examination of specific case-studies to illustrate the evolution of ESC rights in Canada.

In the Morgentaler, ${ }^{35}$ Carter $^{36}$ and Smith ${ }^{37}$ cases, the Court acknowledges that Section 7 requires that governments "refrain from adversely affecting individual physical or psychological health or security". ${ }^{8}$ Additionally, Dianne Pothier notes, in an excerpt cited by the Court in Vriend, that Section 32 is "worded broadly enough to cover positive obligations on a legislature such that the Charter will be engaged even if the legislature refuses to exercise its authority".39 A notable example of the implementation of this concept is the 1989 Irwin Toy case, which dealt with the compatibility between provisions of a Quebec law that prevented the broadcasting of commercial advertising directed at children under 13 years of age and the right to freedom of expression enshrined in Section 2 (b) of the Charter. In this case, the Court dismissed an attempt to include the right

33 Katharine Young, Constituting Economic and Social Rights: The Path to Transformation, Abstract (Oxford: University Press, 2012), available at SSRN: https://ssrn.com/abstract=2419986. See also a more recent study by the same author: Katharine Young, The Future of Economic and Social Rights (Cambridge: Cambridge University Press, 2019).

34 Jackman and Porter, Advancing Social Rights in Canada, Introduction, 14.

35 R v. Morgentaler, 1 SCR 30 (1988).

36 Carter v. Canada (Attorney General), 1 SCR 331 (2015).

37 R v. Smith, 2 SCR 602 (2015).

${ }^{8}$ Jackman and Porter, "Social and Economic Rights," 851.

39 Dianne Pothier, "The Sounds of Silence: Charter Application When the Legislature Declines to Speak," Constitutional Forum 7 (1996): 115. 
to property in the constitution through Section 7 of the Canadian Charter on the basis that such a right had been voluntarily excluded from the Charter. ${ }^{40}$ In doing so, the Court made sure to differentiate between economic rights in the commercial and corporate sense, and the economic rights included in various international treaties as defined, for example, in the ICESCR. ${ }^{41}$ The Court had concluded that it would have been hasty to exclude the latter at such an early stage in the interpretative process of the Charter. ${ }^{42}$

This decision proved to be enlightening as to the tone that the Court has adopted with regard to the recognition of ESC rights, at times acting as guardian of said rights, and at others contributing to their fragility. Most often, it is precisely the Court's inaction and restraint that has proved damaging to such recognition rather than any positive action directed against it. As proof of this assertion, in the first two decades following this decision, most of the lower Canadian courts rejected economic and social rights claims on the basis of their alleged exclusion from Section 7 of the Charter, despite the Supreme Court's warning. ${ }^{43}$ However, the window left ajar by the Supreme Court in relation to Article 7 was not addressed in any way until 2002. ${ }^{44}$

The question was raised again in Gosselin, a landmark decision with regard to ESC rights in Canada, which will be discussed in more detail below. ${ }^{45}$ In this case, the Court had to consider the constitutionality of a regulation that substantially reduced the benefits of social assistance to recipients under the age of 30 who were not participating in labour market reintegration programs. ${ }^{46}$ Thus, in short, the Court had to decide whether, in light of Section 7 of the Charter governments had a positive obligation to ensure that those in need received a sufficient amount of public welfare benefits to meet their basic needs. ${ }^{47}$ Faithful to its usual approach, rather than deciding whether there was (or was not) such

\footnotetext{
40 Irwin Toy Ltd v. Québec (Attorney General), 1 SCR 927 (1989), par. 1003.

${ }_{41}$ Irwin Toy Ltd v. Québec.

42 Irwin Toy Ltd v. Québec.

43 Martha Jackman, "Poor Rights: Using the Charter to Support Social Welfare Claims," Queens Law Journal 19 , no. 65 (1993): 75 .

44 Jackman and Porter, "Social and Economic Rights," 849.

45 Gosselin v. Quebec (Attorney General), SCC 84 (2002).

${ }^{6} 6$ Gosselin v. Quebec.

47 Gosselin v. Quebec.
} 
an obligation, the Court merely indicated that in this particular case the facts did not justify the recognition of a positive obligation imposed by these rights..$^{8}$ The Court therefore indicated that such an interpretation remained possible in a future case, but that in this instance the presence of compensatory clauses based on the work accomplished and the absence of evidence of significant hardship arising from this regulation did not trigger such an obligation. ${ }^{49}$

In the 2005 Chaoulli case, the Supreme Court contended that though the Charter "does not confer a freestanding constitutional right to healthcare,"50 the fact that medical services in the public healthcare system were delayed in the province of Quebec meant that patients' rights to life, physical and psychological security were violated..$^{51}$ The majority of the Court concluded that residents of the province of Quebec should be allowed to take out private insurance plans in order to access private medical services and that the legislation prohibiting them from doing so had to be struck down..$^{2} \mathrm{~A}$ few years later, the Toussaint case highlighted that much uncertainty remains with regards to challenging healthcare access as a violation of Sections 7 and 15 of the Charter. Both the Federal Court and the Federal Court of Appeal found that Toussaint's, an irregular migrant, access to healthcare was not to be funded by the Canadian government's Interim Federal Health Program despite the woman's "risk [being] significant enough to trigger a violation of her rights to life and security of the person".53 Justice Mactavish, in the context of the Canadian Doctors for Refugee Care case, further noted that "the Charter's guarantees of life, liberty and security of the person do not include the positive right to state funding for health care". ${ }^{44}$

However, in 2011, the Supreme Court considered the PHS Community Services (Insite) case, whereby the plaintiffs claimed that the federal government's failure to concede an exemption to the Controlled Drugs and Substances Act for Insite's supervised drug injection site resulted in a violation of Section 7 and that the

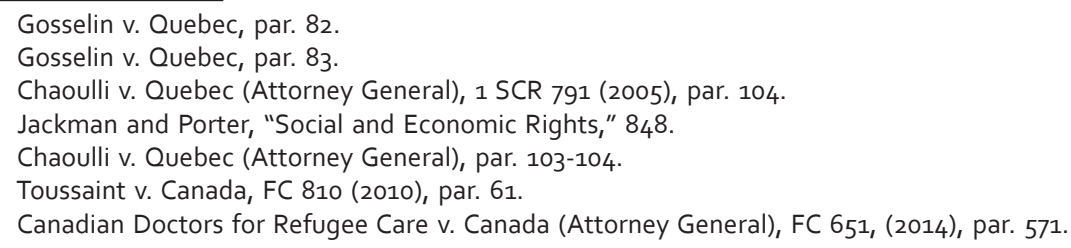


organization's permit should be renewed. 55 The Court concluded that "denial of access to the health services provided at Insite violates its clients' [Section 7] rights to life, liberty and security of the person". ${ }^{56}$

The long-term practical effect of simply suggesting that such a positive obligation could exist without ever commenting on its content is to negate that very possibility. Evidence of this is provided by the fact that the Supreme Court's approach to the recognition of ESC rights under Section 7 of the Charter remains inconclusive to this day. Such an assertion requires thus an examination of the development of ESC rights under the aegis of Article 15 of the Charter, the right to equality.

The first Supreme Court decisions that dealt with ESC rights through Section 15 of the Charter were crucial to lay the foundation for an opportunity to claim ESC rights through the Charter. The Court thus interpreted the right to equality to include essential dimensions of ESC rights and to impose positive obligations on the government to address inequalities. ${ }^{57}$ In Schachter, the Court acknowledged that social assistance programs for single mothers are encouraged by Article 15 of the Charter and justified positive legal remedies for overly restrictive programs on these grounds..$^{58}$ Several lower courts followed the lead of the Supreme Court by recognizing the role of systemic discrimination on the basis of poverty and accepting it as similar to the categories of discrimination already comprised by Article 15 of the Charter. ${ }^{59}$ Be that as it may, the Court has not explicitly recognized the positive dimension of said rights to ensure substantive equality, namely the state's obligation to provide social programs to meet the needs of people experiencing poverty. ${ }^{60}$ The Court also failed to answer the question as to whether the social condition of poverty should be formally recognized as a prohibited ground for discrimination under Article $15 .{ }^{61}$

\footnotetext{
Canada (Attorney General) v. PHS Community Services Society, SCC 44 (2011).

Canada (Attorney General) v. PHS Community Services Society, par. 93.

57 Jackman and Porter, "Social and Economic Rights," 850.

8 Schachter v. Canada, 2 SCR 679 (1992), par. 41.

59 See for example: Dartmouth/Halifax County Regional Housing Authority v. Carvery, NSJ No 96 (NCSA), (1993); Falkiner v. Ontario (Ministry of Community and Social Services), OJ No 1771 (ONCA), (2002).

60 Jackman and Porter, "Social and Economic Rights," 850.

61 Jackman and Porter, "Social and Economic Rights."
} 
The Auton case from 2004 demonstrates that despite advances made by the Eldridge case in terms of the right to equality, where the Supreme Court concluded that the government of British Columbia had to provide sign language interpretation when administering medical services ${ }^{62}$, there exists no automatic obligation for governments to instill specific social or health programs. As Justice McLachlin stated: "this Court has repeatedly held that the legislature is under no obligation to create a particular benefit. It is free to target the social programs it wishes to fund as a matter of public policy, provided the benefit itself is not conferred in a discriminatory manner". ${ }^{63}$ As such, the Court decided that the decision of British Columbia's government to not fund a healthcare program for autistic children did not violate their right to equality under Article $15 .{ }^{64}$

Although there have been strides in acknowledging that economic, social and cultural rights could be recognized as constitutional entitlements ${ }^{65}$, there is still a long way to go. As put by Jackman and Porter: "section 15 has yet to fully deliver on its promise of substantive equality for disadvantaged groups seeking remedies not only for inequitable but for inadequate social programs and policies. The question, left open by the Supreme Court in Irwin Toy, of whether section 7 should be interpreted to include social and economic rights such as the right to food, housing or social security, also remains unanswered".66

Indeed, it is important to focus on the Supreme Court's progress in this direction and to try to illustrate what the future is likely to hold for the pursuit of the constitutional protection of ESC rights. More specifically, we will do so through Section 7 of the Charter and take as a case study the Supreme Court's decision in Gosselin, ${ }^{67}$ which we briefly discussed above. Despite our conclusion that the framework proposed by the Court has shown disappointing results, considering this judgment's importance, an in-depth study of the ins and outs

62 Eldridge v. British Columbia (Attorney General), 3 SCR 624 (1997).

${ }_{63}$ Auton (Guardian ad litem of) v. British Columbia (Attorney General), 3 SCR 657 (2004), par. 41.

64 Auton (Guardian ad litem of) v. British Columbia (Attorney General).

65 Louise Arbour, "Freedom from Want, From Charity to Entitlement" (LaFontaine-Baldwin Lecture, 2005). Accessed at: https://archive.macleans.ca/article/2005/3/14/freedom-from-want.

66 Jackman and Porter, "Social and Economic Rights, 859.

67 Gosselin, SCC. 
of its analysis of Article 7 of the Charter is required to understand some of the possible ways to move forward.

The Court's decision in Gosselin, while disappointing in some respects, made significant progress in recognizing essential components of ESC rights. A brief recap of the facts is required. Louise Gosselin, as the representative of the province's under-30 social assistance recipients, sued the Government of Quebec through a class-action lawsuit. ${ }^{68}$ She was seeking to declare unconstitutional Section 29 (a) of the Regulation respecting Social Aid. ${ }^{69}$ The provision reduced the amount claimable as financial assistance for individuals under 30 years of age to one-third of the "basic needs amount" provided for in Article 23 of the Regulation, which allowed them to meet their most basic needs. ${ }^{70}$ The appellant therefore claimed that the provision of the regulation violated her right to security of the person under Section 7 of the Canadian Charter, her right to be protected from discrimination on the basis of age under Section 15, and finally her right to "an acceptable standard of living" under Section 45 of Quebec's Charter of Human Rights and Freedoms. ${ }^{11}$

The relevant question before the Court was whether to passively block governmental actions violating the rights contained in Article 7. Alternatively, was the government also forced to ensure that it guaranteed some economic assistance to people in need to avoid for its inaction to have the effect of violating their right to life, liberty and security? A view widely supported by provincial and federal governments, would be to eliminate the possibility of recognizing any positive dimension to the right to life, liberty and security of the person..$^{72}$ This argument was based partly on the placement of Article 7 in the Charter, which would supposedly indicate that it concerns only the interaction of individuals with the administration..$^{73}$ The other facet of the argument was democratic in

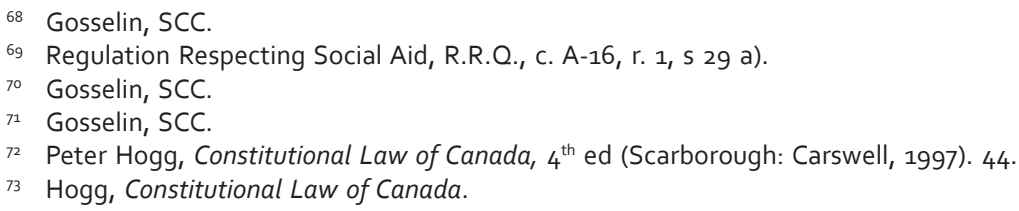


nature, i.e., to include positive obligations in Section 7 would have the effect of placing political issues under the jurisdiction of the courts. ${ }^{74}$ We'll come back to this argument throughout our analysis to demonstrate that while the Court has justified part of its decision on the basis of democracy, other political motives may have been the driving factor.

In short, an attempt was made to limit the application of Section 7 to protection against direct state intervention that would harm the person's physical and psychological integrity. This interpretation of Section 7 was vigorously rejected in Gosselin, while 8 of the 9 judges of the Supreme Court concluded that it was not applicable. ${ }^{75}$ The majority concluded that although Section 7 had so far been interpreted as a negative guarantee preventing the state from depriving citizens of the rights protected therein, this did not preclude its possible application in the future. ${ }^{76}$ The majority subsequently mentioned that such an application would depend on the circumstances, as the present case did not allow positive obligations to be triggered. ${ }^{77}$ Justice Louise Arbour, in dissent, went even further by affirming that such positive obligations existed in this particular case. In particular, she pointed out that by refusing to apply them in this case, the Court was going against its own case law in a previous judgment. $7^{7}$

Some might argue that such a conclusion does not give cause for celebration. However, the effect of the Court's conclusion is undeniable: it opens the door to the recognition of positive obligations for ESC rights through Article 7. It does so by making it conditional upon the presence of certain circumstances. Therefore, such circumstances must exist, or at least the Court must be receptive to their existence if the situation warrants it, which is a giant step forward in the evolution of ESC rights as constitutional obligations.

\footnotetext{
Hogg, Constitutional Law of Canada.

Gosselin, SCC.

Gosselin, SCC, par. 82.

Gosselin, SCC, par. 83.

Gosselin, SCC, par. 324 .
} 


\section{THE ACHILLES' HEELS OF ESC RIGHTS: THE JURISPRUDENTIAL CONSTRUCTION OF THE POSITIVE/ NEGATIVE DICHOTOMY}

While most provinces have adopted poverty reduction plans, none of them has implemented a strong rights-based approach. ${ }^{9}$ Most of these measures do not hold the government accountable nor do they impose positive obligations towards it. Such advances are part of a process towards a purpose that cannot be achieved overnight. The pressure exerted by anti-poverty groups is not in vain; it raises awareness among the population and governments about the difficulties faced by the poor in their everyday lives. The laws and strategies put in place by governments are also essential, they send a message that this is a key concern.

In light of this, the question arises as to how a full recognition of the positive dimension of ESC rights has not been fully realized in Canada. Over the last few decades, multiple apex courts in a variety of countries have progressively contributed to the decay of ESC rights by rendering judgments at odds with the nature of such rights. ${ }^{80}$ Indeed, the growing popularity of neoliberalism among political elites has pressured courts into adapting judicial systems to fit this new paradigm $^{81}$. In turn, the question of how ESC rights were to take shape within these new structures would soon arise. Indeed, as neoliberalism is founded on the premise of limited state intervention in the economy and faith in the free market, its compatibility with ESC rights is far from clear at a foundational level. Therefore, if there were to be ESC rights (or any rights for that matter) in such a system, they had to be redefined so as to coexist with the central values of neoliberalism. Although Canada has not completely deviated from this global trend, the path it has taken differs slightly. This section highlights how some of these values specifically made their way into Canadian constitutional law by identifying the methods the Courts have used to accommodate a neoliberal ideology at the expense of ESC rights.

\footnotetext{
79 Martha Jackman and Bruce Porter, "International Human Rights and Strategies to Address Homelessness and Poverty in Canada: Making the Connection," (Working Paper, University of Ottawa Faculty of Law Legal Studies no. 09, 2013), 36.

80 Paul O'Connell, "The Death of Socio-Economic Rights," Modern Law Review 74, no. 4 (July 2011): 532-554

${ }^{81}$ Paul O'Connell, "The Death of Socio-Economic Rights."
} 
Before going any further, it is important to identify some of the relevant fundamental precepts that typically underlie the neoliberal vision. As with any political ideology, its followers are often guided by common narratives, guidelines that will accompany them in their decision-making process. As judges are no exception to this, we will try to pinpoint what these narratives are and how they are exploited in a judicial setting. Such a process isn't necessarily fluid and certainly does not have to be overt or intentional. In fact, it is a lot more likely to be implicit and progressively implemented through judicial interpretation ${ }^{82}$. Nevertheless, the many inconsistencies that will arise from this study will demonstrate that such a bias is indeed prevalent. One of the tenets of neoliberalism that is particularly important to our analysis is the commodification of the individual's role in society. ${ }^{83}$ In other words, the individual is to be rewarded or supported according to his or her productivity or eventual ability to be productive. Productivity is thus associated with merit; the individual is responsible for his or her own success or failure. ${ }^{84}$ Another important facet is the idea of skepticism towards the state, which is seen as burdensome and unproductive, as opposed to the market which benefits society as a whole through its efficiency and economic prowess. ${ }^{85}$ This phenomenon notably explains the emphasis by political elites on negative rights (which protect individual freedom) as opposed to positive rights (which typically require the redistribution of resources by the state), leaving little place for ESC rights to prosper. ${ }^{86}$

Based on global trends, there are usually two main ways for these transitions to occur, depending on whether or not the rights are textually provided for in the constitution. ${ }^{87}$ In the case that they aren't, which is Canada's situation as we've discussed previously, Courts usually tend to recognize solely the negative dimension of constitutional rights and seize the opportunity to frame ESC

David Schneiderman, Constitutionalizing Economic Globalization (Cambridge: Cambridge University Press, 2007$) 2$.

83 Paul O'Connell, "The Death of Socio-Economic Rights," 535.

84 Lisa Philipps, "Taxing the Market Citizen: Fiscal Policy and Inequality in an Age of Privatization," Law and Contemporary Problems (2000) 63: 115.

85 Paul O'Connell, "The Death of Socio-Economic Rights," 535.

${ }^{86}$ Craig Scott and Patrick Macklem, "Constitutional Ropes of Sand or Justiciable Guarantees? Social Rights in a New South African Constitution,", University of Pennsylvania Law Review 141 (1992): 1, 26.

87 Paul O'Connell, "The Death of Socio-Economic Rights," 532-554, 539. 
rights in a procedural role at most. ${ }^{88}$ As we will see, this isn't the path Canada has taken. How, then, has the Supreme Court of Canada arrived at similar outcomes without explicitly excluding the positive dimension of ESC rights, as is the case in other jurisdictions? It is in the transition from theory to practice that the Court has tacitly acted. Where the problem lies is in the assessment of the previously mentioned circumstances required to trigger positive obligations. Indeed, we argue that the Court cannot, on the one hand, impose conditions on the application of positive obligations through Article 7 of the Charter and, on the other hand, vitiate this possibility in practice. In order for the Court's postulate to stand, its approach must remain consistent when it is applied.

The assessment of evidence at trial is central in evaluating if the "circumstances" will in turn exceed the threshold necessary for the application of positive obligations to be triggered. ${ }^{89}$ For example, the trial judge in Gosselin proposed an approach based on a series of biases to argue that the evidence was insufficient to justify the violation of Section 7 of the Charter. By neglecting the robust evidence proposed by Louise Gosselin regarding the harm suffered as a result of the regulation, one may wonder whether the basis of his argument reflects a legitimate analysis.

Here we encounter our first "common narrative" as the trial judge emphasized the individual's role in securing his or her own welfare by resorting to strength of character. Commenting on the archetypal ideal citizen of a neoliberal system, Philipps writes: "The ideal citizen of neoliberal discourse is responsible to secure his or her own welfare through market activity, family resources, and, if necessary, charity, resorting to government assistance only in the most desperate circumstances. (...) The egalitarian vision of social citizenship, still incompletely realized, is being displaced by a norm of market citizenship in which inequalities are attributed to individual merit or failures, and social rights are displaced by economic rights to private property and free markets." The parallel is staggering when compared with the trial judge's vision of poverty. In particular, the trial judge

\footnotetext{
88 Paul O'Connell, "The Death of Socio-Economic Rights."

89 Martha Jackman, "One Step Forward and Two Steps Back Poverty, the Charter and the Legacy of Gosselin," National Journal of Constitutional Law 39, no. 85 (2019): 103.
} 
mentioned that the main cause of poverty stems from intrinsic characteristics, with external factors playing a secondary role in this regard. ${ }^{\circ}$ He also stated the following "Indeed, it is constant that the human being who has developed the qualities of strength, courage, perseverance and discipline generally overcomes and masters the educational, psychic and even physical obstacles that could lead him into material poverty" (Authors' translation). ${ }^{91}$ In response to his argument, the Chief Justice of the Supreme Court, writing for the majority, unreservedly supported the trial judge's conclusion in his interpretation of the evidence.92 This enabled the Court to avoid directly addressing the question, and instead, to defer to the trial judge's assessment of the evidence. In contrast, the standard used to approve the probative value of the evidence presented by the government did not appear to have been the same as Louise Gosselin's. ${ }^{93}$ The government, for its part, had not provided any concrete evidence that the regulation would promote the integration of young underprivileged people into the labour market in order to lift themselves out of poverty. ${ }^{94}$ However, the Chief Justice of the Supreme Court was quick to acknowledge the likely effectiveness of the program in this regard. ${ }^{95}$ Indeed, this strong inclination to favour assistance conditional on eventual productivity is also revealing. As Philipps writes: "Public services once associated with universal social rights are increasingly restricted, means-tested, and made more closely conditional upon efforts to engage in paid labour." ${ }^{96}$

The dissenting judges, by contrast, treated the evidence presented at trial with far greater rigour, which could explain the very different results that ensued. ${ }^{97}$ Justice Arbour, for example, pointed out that many barriers prevent people experiencing poverty from doing an effective job search, considering the optimal conditions to do so often rely on financial ability. ${ }^{98}$ Justice Lebel, for his

Gosselin v. Québec (Procureur général [Attorney General]), R.J.Q. 1647 (C.S. Que.) (1992), 1670.

91 Gosselin v. Québec, 1676.

92 Gosselin, SCC, par. 46-47.

93 Martha Jackman, "One Step Forward and Two Steps Back: Poverty, the Charter and the Legacy of Gosselin," National Journal of Constitutional Law 39, no. 85 (2019):104.

94 Martha Jackman, "One Step Forward and Two Steps Back: Poverty."

95 Gosselin, SCC, par. 43.

96 Lisa Philipps, "Taxing the Market Citizen: Fiscal Policy and Inequality in an Age of Privatization," Law and Contemporary Problems 63(2000): 116.

97 Jackman, "One Step Forward and Two Steps Back: Poverty," 106.

$9^{8}$ Gosselin, SCC, par. 392. 
part, pointed out that social assistance recipients in the 1980s were not lazy but rather victims of the economic conditions that had created high unemployment in the first place. ${ }^{99}$ The way the majority and the dissenting judges looked at the evidence sparks a sharp contrast in terms of the depth of the analysis, the former paying less attention to contextual elements. In order to render a fair decision, judges must evaluate the evidence in a neutral manner. But above all, they must not conclude in advance that the circumstances do not justify the application of positive obligations through Section 7 of the Charter by tendentiously neglecting the evidence presented by the plaintiff.

Another problem with the majority's reasoning, the result of which is equally problematic, is that it distorts the position of the complainants. Indeed, the Court refrains from answering Louise Gosselin's question precisely, namely whether in this case the regulation reducing social assistance for people under 30 years of age to one-third of the previous amount violated Article 7 of the Charter. ${ }^{100}$

Instead, the Court rephrases this argument as an abstract and biased position. It questions whether Section 7 of the Charter guarantees a right to an adequate amount of social assistance. ${ }^{101}$ The way a question is asked can obviously have significant impacts on the answer. Asking the question in the abstract also significantly increases the task of the plaintiffs, especially when the evidence they have to present isn't as relevant to the amended interrogation that the Court poses. The factual evidence of this issue is once again reflected in Justice Arbour's dissent. Instead of modifying it, she answered the appellants' question as it was asked: it was clear to her that the regulation had a negative impact on the safety of those who were affected by it. ${ }^{102}$ She therefore concluded that Section 7 had indeed been violated. ${ }^{103}$ Under the guise of neutrality, it's clear that the Court sought to answer the question before even asking it. This is indicative of the ideological bias that such an attitude betrays. The evidence presented by complainants that their right to security was in fact violated by government

99 Gosselin, SCC.

100 Jackman, "One Step Forward and Two Steps Back: Poverty," 106.

101 Gosselin, SCC, par. 76.

${ }_{102}$ Gosselin, SCC, par. 373.

${ }_{103}$ Gosselin, SCC, par. 377. 
action will very rarely be useful in answering the question of whether the Charter allows for any economic assistance.

One might wonder what to remember from the Gosselin case for years to come. In theory, one would think that the conclusion in Gosselin is between a success and a failure for ESC rights in that it allows for the possibility of recognizing positive obligations, but that it adopts a partisan stance against that very possibility before even answering the question. Unfortunately, time has told a completely different story in that the decision in Gosselin was used instead as an argument by the lower courts to reinforce the notion that Section 7 does not impose positive obligations on the Government to recognize ESC rights. ${ }^{104}$ In our opinion, the Court has played an active role in this result.

The case of Tanudjaja $v$ Canada before the Superior Court of Ontario is a good illustration of this. ${ }^{105}$ Jennifer Tanudjaja was a homeless person who alleged that the effect of the inadequacy of the various housing and social assistance policies of the Canadian and Ontario governments had resulted in increased homelessness, violating her rights under Sections 7 and 15 of the Charter. Indeed, in this case, the trial judge went a step further by stating: "Section 7 of the Charter does not provide a positive right to affordable, adequate, accessible housing."106 This is a highly startling statement as it is more than clear that in Gosselin, the Court leaves open the possibility that such a conclusion can be reached. While it is true that the question of whether such a positive obligation applied in this case remains debatable, it is most certainly false to claim that such a positive obligation cannot exist. Following a mitigated decision of the Ontario Court of Appeal, it would have been quite normal to assume that the Supreme Court would rectify the situation or at least comment on it. ${ }^{107}$ Yet, the Court simply refused to hear the appeal. In fact, it has done the same for countless similar situations in the past years. ${ }^{108}$ This is one important way in which the Supreme Court has differed from other apex courts around the world, while it has not

\footnotetext{
104 Jackman, "One Step Forward and Two Steps Back: Poverty," 108.

105 Tanudjaja v. Canada (Attorney General), ONSC 5410 (2013).

106 Tanudjaja v. Canada (Attorney General), par. 81.

107 Tanudjaja v. Canada (Attorney General), ONCA 852 (2014).

108 Jackman, "One Step Forward and Two Steps Back: Poverty," 114.
} 
itself shut down the possibility of a positive dimension to Charter rights, it has tacitly prevented it from happening through the lower courts by remaining silent.

There is one notable exception to the Court's refusal to hear appeals on poverty-related issues. The one time it did, it was to hear a complainant seeking to use Section 7 of the Charter to demand the right to have easier access to the private health system at the expense of the public one. ${ }^{109}$ The Court proceeded with the opposite reasoning as in Gosselin although the principle was the same. This time, the Court did not claim that its intervention would constitute judicial interference in what was supposed to be a political matter. Indeed, as deferral to the legislative branch on questions relating to positive rights is often justified on the basis of democracy, ${ }^{110}$ the Court was quick to intervene when it came to the question of access to the private system.

Furthermore, rather than asking whether the complainant had a right to a private health care system in the abstract, it asked whether his life, liberty and security had been violated by the effect of the law in question. ${ }^{11}$ This suggests that there is a double standard for the Court when it comes to the recognition of positive obligations in relation to ESC rights. For the time being, it has not fulfilled its role of unambiguously resolving this issue. This abdication reflects two particularly alarming ideas. First, the practical effect of the Supreme Court's refusal to adopt a clear position on the subject by refusing to hear appeals is that of an unequivocal refusal by the lower courts to recognize positive obligations for ESC rights through Article 7, contrary to its teachings in Gosselin. Second, that it does not appear coincidental that such an ambiguity persists.

\section{FROM UTOPIA TO REALITY: THE PATH AHEAD FOR ESC RIGHTS IN CANADA}

Writing over three decades ago, Professor Martha Jackman argued that "where a community is firmly committed to a set of values, aspirations or traditions, the constitution properly interpreted, will surely come to reflect their existence."12

\footnotetext{
109 Chaoulli v. Quebec (Attorney General), SCC 35 (2005).

110 Paul O'Connell, "The Death of Socio-Economic Rights," Modern Law Review 74, no. 4 (July 2011 ): 539.

111 O'Connell, "The Death of Socio-Economic Rights," 108.

112 Jackman, "The Protection of Welfare Rights Under the Charter," 338.
} 
International recognition and domestic implementation of ESC rights have come a long way in the past 30 years, and so has the evolution of the interpretation of fundamental rights in the Charter.

The words of Ran Hirschl resonates as far as the evolution of ESC rights in Canada is concerned:

"All of the fundamentals of neoliberal social and economic thinking (such as individualism, deregulation, the commodification of public services, and reduced social spending) owe their origins to the same concepts of antistatism, social atomism, and strict protection of the private sphere that are currently enjoying dominance in the discourse of rights." ${ }^{13}$

It seems like most of these concepts have progressively and subtly made their way into Canadian case law. In 1986, when the Court had to decide whether or not there was a constitutionally protected right to property, its response was categorical as to the non-existence of such a right. ${ }^{114}$ In 2021, the future of ESC rights through Article 7 of the Charter remains uncertain. It may be argued that the Court maintains the status quo because it is well aware of the gravity of excluding the positive obligations of ESC rights from constitutional protection in view of the significant advances they could foster in protecting the right to life, liberty and security. The result is that we're left with this blurry framework that seems to be highly influenced by current political and economic factors, which has worked against full recognition of the positive dimension of ESC rights as of today.

While many ESC rights are effectively protected by specific legislation, the highest level of recognition of ESC rights within Canada requires constitutional protection of those rights. As discussed, the Charter is silent as to ESC rights. Court decisions have not come as far as recognizing ESC rights through the interpretation of fundamental rights enshrined in the Charter. In the evolution of the Charter jurisprudence, some light has entered through half-closed doors in cases concerning life, liberty and security of the person (Section 7), and equality protection rights (Section 15). This paper reviewed the jurisprudential

113 Ran Hirschl, Towards Juristocracy (Cambridge, MA: Harvard University Press, 2004), 147.

114 Irwin Toy Ltd v. Québec, par. 1003. 
construction of ESC rights in Canada. The positive/negative dichotomy has proved to be the Achilles' heel in full protection of ESC rights. In order to fully meet its international obligations, and lead the way in ESC rights, more needs to be done. While superficially it may seem that Canada scores high on ESC rights, the reality is far from a utopian picture.

\section{BIBLIOGRAPHY}

Act to Combat Poverty and Social Exclusion, CQLR c L-7 (2002).

Alston, Philip and Ryan Goodman. International Human Rights, Oxford: Oxford University Press, 2013.

Arbour, Louise. "Freedom from Want, From Charity to Entitlement." (LaFontaineBaldwin Lecture, Quebec City, 2005).

Auton (Guardian ad litem of) v. British Columbia (Attorney General), 3 SCR 657 (2004).

Baker v. Canada (Minister of Citizenship and Immigration), 2 SCR 817 (1999).

Brun, Henri, Guy Tremblay, and Eugénie Brouillet. Droit Constitutionnel [Constitutional Rights] $6 \mathrm{t}^{\mathrm{h}}$ edition (Cowansville: Editions Yvon Blais, 2008).

Canada (Attorney General) v. PHS Community Services Society, SCC 44 (2011).

Canadian Charter of Rights and Freedoms, Part I of the Constitution Act, (1982), being Schedule B to the Canada Act of 1982 (UK), (1982), c. 11.

Canadian Doctors for Refugee Care v. Canada (Attorney General), FC 651, (2014). Carter v. Canada (Attorney General), 1 SCR 331 (2015).

Chaoulli v. Quebec (Attorney General), SCC 35 (2005).

Chaoulli v. Quebec (Attorney General), 1 SCR 791 (2005).

Constitution Act, (1982), sec. 35, being Schedule B to the Canada Act 1982 (UK), (1982), c. 11, sec. 52 .

Currie, John H. et al. International Law: Doctrine, Practice and Theory, $2^{\text {nd }} e d$., Toronto: Irwin Law, 2014. 
Dartmouth/Halifax County Regional Housing Authority v. Carvery, NSJ No 96 (NCSA), (1993).

Eldridge v. British Columbia (Attorney General), 3 SCR 624 (1997).

Falkiner v. Ontario (Ministry of Community and Social Services), OJ No 1771 (ONCA), (2002).

Gosselin v. Quebec (Attorney General), SCC 84 (2002).

Gosselin v. Québec (Procureur général [Attorney General]), R.J.Q. 1647 (C.S. Que.) (1992).

Hirschl, Ran. Towards Juristocracy. Cambridge, MA: Harvard University Press, 2004.

Hogg, Peter. Constitutional Law of Canada, $4^{\text {th }}$ ed., Scarborough: Carswell, 1997. International Covenant on Civil and Political Rights, Dec. 19 ,1966, 999 UNTS 171 (entered into force March 1976, accession by Canada May 19, 1976).

International Covenant on Economic, Social and Cultural Rights, Dec. 16, 1966, 993 UNTS 3 (entered into force Jan. 3, 1976, accession by Canada May 19, 1976).

Irwin Toy Ltd v. Québec (Attorney General), 1 SCR 927 (1989).

Jackman, Martha and Bruce Porter. Advancing Social Rights in Canada, Introduction. Toronto: Irwin Law, 2014.

Jackman, Martha. "One Step Forward and Two Steps Back Poverty, the Charter and the Legacy of Gosselin." NJCL 39, no. 85 (2019).

Jackman, Martha. "Poor Rights: Using the Charter to Support Social Welfare Claims." Queens Law Journal 19, no. 65 (1993).

Jackman, Martha. “The Protection of Welfare Rights Under the Charter", Ottawa Law Review 20 (1988).

Jackman, Martha and Bruce Porter. "International Human Rights and Strategies to Address Homelessness and Poverty in Canada: Making the Connection." Working paper, Faculty of Law and Legal Studies, University of Ottawa, Ontario, 2013. 
Jackman, Martha and Bruce Porter. "Socio-Economic Rights Under the Canadian Charter." In Social Rights Jurisprudence: Emerging Trends in International and Comparative Law, edited by Malcolm Langford. Cambridge, New York: Cambridge University Press, 2008.

Jackman, Martha and Bruce Porter. "Social and Economic Rights." In The Oxford Handbook of the Canadian Constitution, edited by Oliver, Peter, Macklem, Patrick and Des Rosiers, Nathalie. Oxford: Oxford University Press, 2017.

Kwadrans, Ania. "Socioeconomic Rights Adjudication in Canada: Can the Minimum Core Help in Adjudicating the Rights to Life and Security of the Person under the Canadian Charter of Rights and Freedoms?" Journal of Law and Social Policy 25 (2016): 83.

Lamarche, Lucie “The 'Made in Québec' Act to Combat Poverty and Social Exclusion The Complex Relationship between Poverty and Human Rights." In Poverty: Rights, Social Citizenship, and Legal Activism, edited by Young, Margot, Boyd, Susan B., Brodsky, Gwen and Day, Shelagh. Vancouver: UBC Press, 2007.

Langford, Malcolm. "The Justiciability of Social Rights: From Practice to Theory." In Social Right Jurisprudence: Emerging Trends in International and Comparative Law, edited by Malcolm Langford. New York: Cambridge University Press, 2008.

O'Connell, Paul. “The Death of Socio-Economic Rights.” Modern Law Review 74, no. 4 (July 2011).

Philipps, Lisa. "Taxing the Market Citizen: Fiscal Policy and Inequality in an Age of Privatization." Law and Contemporary Problems 63 (2000).

Pothier, Dianne. "The Sounds of Silence: Charter Application When the Legislature Declines to Speak." Constitutional Forum 7 (1996).

R v. Morgentaler, 1 SCR 30 (1988).

R v. Smith, 2 SCR 602 (2015).

Regulation Respecting Social Aid, R.R.Q., c. A-16, r. 1, s 29 a). 
Schabas, William A. and Stéphane Beaulac. International Human Rights Law: Legal Commitment, Implementation and the Charter, $3^{\text {rd }}$ ed. Toronto: Thomson Carswell, 2007.

Schachter v. Canada, 2 SCR 679 (1992).

Schneiderman, David. Constitutionalizing Economic Globalization. Cambridge: Cambridge University Press, 2007.

Scott, Craig and Patrick Macklem. "Constitutional Ropes of Sand or Justiciable Guarantees? Social Rights in a New South African Constitution." University of Pennsylvania Law Review 141, no. 1 (1992).

Scott, Francis R. "Expanding Concepts of Human Rights." In Essays on the Constitution. Toronto: University of Toronto Press, 1977.

Strong Communities through Affordable Housing Act, SO C-6 (2011).

Sunstein, Cass R. "Social and Economic Rights? Lessons from South Africa." Constitutional Forum 123, (2001).

Tanudjaja v. Canada (Attorney General), ONSC 5410 (2013).

Tanudjaja v. Canada (Attorney General), ONCA 852 (2014).

Toussaint v. Canada, FC 810 (2010).

UN Doc. E/CN.4/1998/84/Add.

Young, Katharine. Constituting Economic and Social Rights: The Path to Transformation, Abstract. London: Oxford University Press, 2012. Available at SSRN: https://ssrn.com/abstract=2419986.

Young, Katharine. The Future of Economic and Social Rights. Cambridge: Cambridge University Press, 2019.

Young, Margot. "Charter Eviction: Litigating Out of House and Home." Journal of Law and Social Policy 24, no. 46. (2015). 